\title{
Germ Cell Tumor Located in the Midline of the Anterior Neck
}

\author{
Ön Boyun Orta Hat Yerleşimli Germ Hücreli Tümör
}

\author{
Tatyana PIRDOPSKA, Ivan TERZIEV, Sv. HRISTOVA, W. MLADENOVSKY, R. PETKOV
}

Department of Pathology, Medical University, SOFIA, BULGARIA

\begin{abstract}
Primary germ cell tumors involving midline of the anterior neck are extremely rare. Here we report a 68 -year-old male who was operated due to a mass lesion in the anterior neck with infiltration of the isthmus of the thyroid gland. Histopathological examination revealed a germ cell tumor with extragonadal localization in the anterior neck infiltrating the isthmus of the thyroid gland.
\end{abstract}

Key Words: Germ cell tumor, Extragonadal localization

\begin{abstract}
ÖZ
Ön boyunda orta hat yerleşimli primer germ hücreli tümörler oldukça nadirdir. Burada ön boyunda kitle nedeni ile opera edilen 68 yaşında bir erkek olgu sunulmaktadır. Histopatolojik incelemede ön boyunda tiroid bezinin istmusunu infiltre eden ekstragonadal germ hücreli tümör saptanmıştır.
\end{abstract}

Anahtar Sözcükler: Germ hücreli tümör, Ekstragonadal

\section{INTRODUCTION}

Germ cell tumors frequently occur in the testis and ovary. They originate from germ cells which migrate during the sixth gestation week from yolk sac to male and female gonads (1). Primary germ cell tumors may develop from rests of migrated germ cells by the middle line of the human body. Extragonadal location is described in the mediastinum (25) and central nervous system (pineal gland) (6-9).

\section{CASE REPORT}

A 68-year-old male presented with a tumor in the midline of the neck. The tumor was operated on and total thyroidectomy was performed. There was no other tumor mass discovered in the testis by USG and MRI. The tumor was $6.5 \mathrm{~cm}$ in the greatest dimension and the cut surface of the tumor was yellow-gray with zones of hemorrhage and necrosis.

Histologically, tumor cells were uniform, with abundant clear cytoplasm sharply outlined cell membranes, a large centrally located nucleus, with one or two prominent nucleoli.

The tumor cells were typically arranged in nests outlined by fibrous bands; these bands were infiltrated by lymphocytes, plasma cells and multinucleated giant cells (Figures 1,2).

Received : 25.08 .2010

Accepted : 04.05.2011
Immunohistochemically the tumor cells exhibited reactivity for placental alkaline phosphatase (PLAP) (Figure 3) and CD117 ( Figure 4), and were negative for cytokeratin AE1-AE3, alpha1-fetoprotein and human chorionic gonadotropin (hCG).

\section{DISCUSSION}

Germ cell tumors with localization in the gonads are well known in pathology practice. They are known as seminoma in the testis and dysgerminoma in the ovary. They have a typical histological appearance: proliferation of large cells arranged in sheets nests, and cords; the tumor cells are relatively large, but uniform, and have a distinct cell membrane. They contain a centrally located, large, round nucleus, which has a sharp nuclear membrane, with one or two prominent nucleoli. The cytoplasm is abundant and clear, but may be eosinophilic or amphophilic.

Immunohistochemically the tumor cells exhibit intermediate to high cytoplasmic reactivity for PLAP, CD117 (10,11). They are negative for cytokeratin AE1-AE3, alpha1-fetoprotein and hCG.

Extragonadal localization is a rarity, and to exclude primary germ cell tumor of male and female gonads is a necessity. This case is valuable due to its rarity.

Correspondence: Tatyana PIRDOPSKA

Department of Pathology, Medical University, SOFIA, BULGARIA

E-mail: titia@abv.bg Phone: +359888973870 


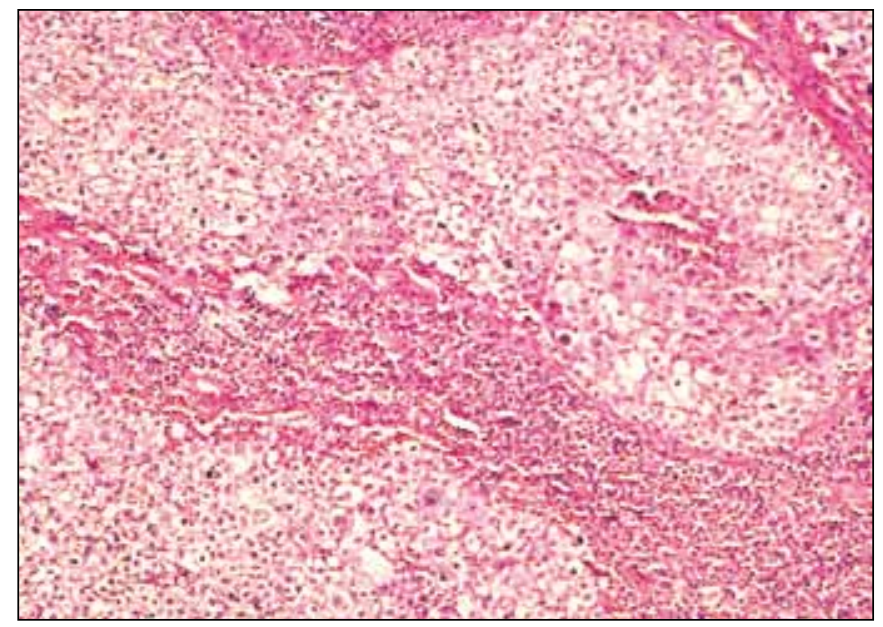

Figure 1: Germ cell tumor, (H\&E; x40).

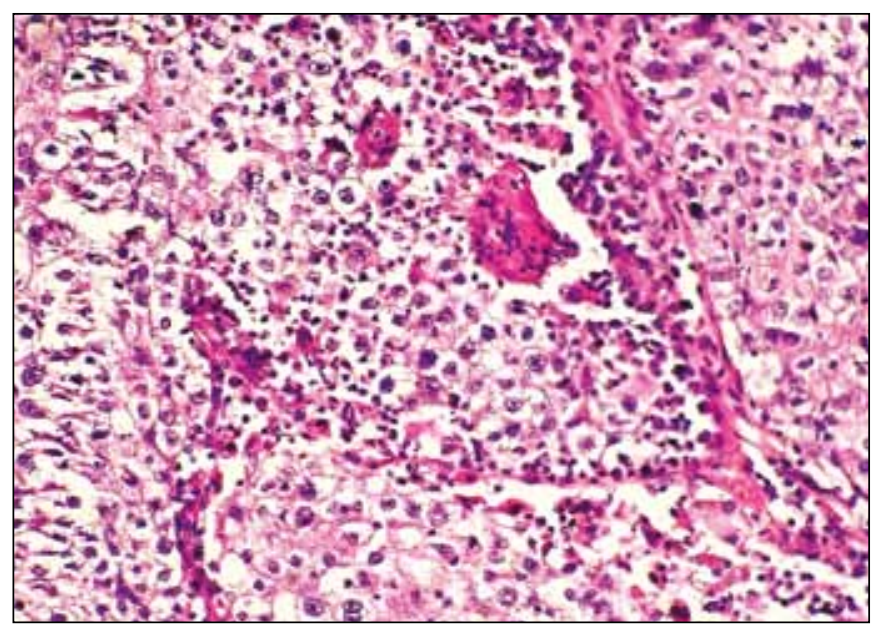

Figure 2: Germ cell tumor consisting of monotonous cell population divided into lobules by thin bands of fibrovascular stroma. Numerous lymphocytes and scattered Langhans-type giant cells, (H\&E; x200).

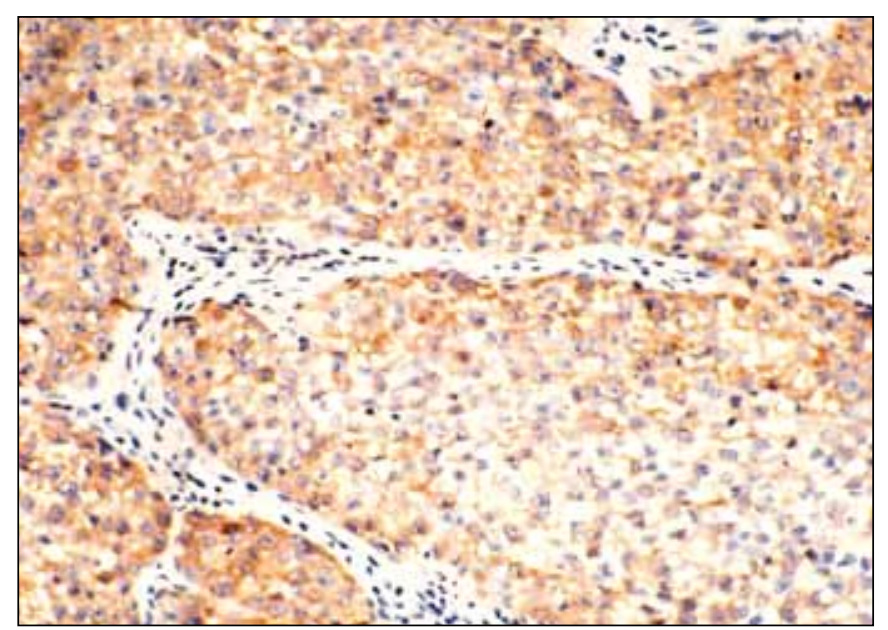

Figure 3: Diffuse positive membranous immunostaining of germinoma cells for placental alkaline phosphatase, (H\&E; x100).

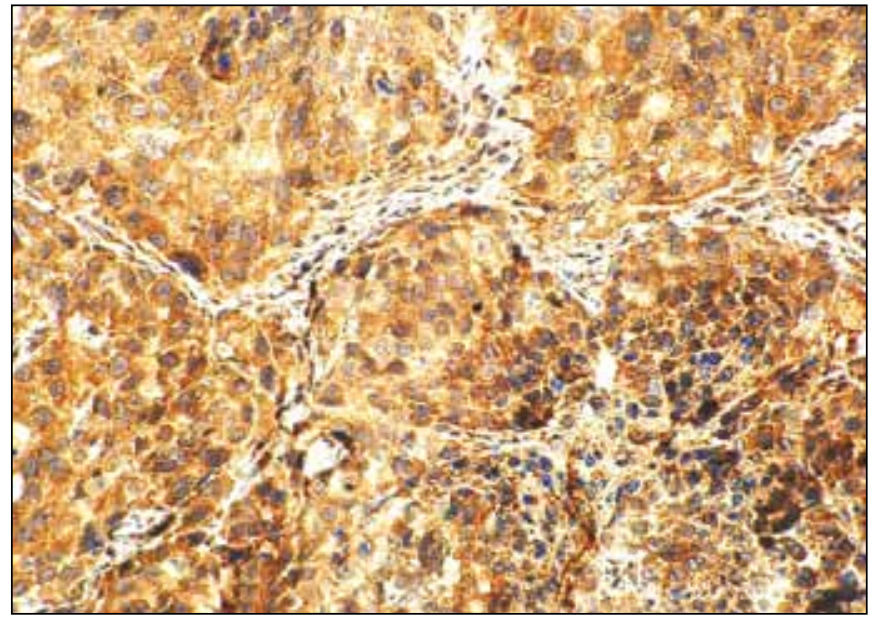

Figure 4: Diffuse immunostaining for CD 117 (x200).

\section{REFERENCES}

1. Friedman NB: The function of the primordial germ cell in extragonadal tissues. Int J Androl 1987, 10:43-49

2. Chaganti RS, Rodriguez E, Mathew S: Origin of adult male mediastinal germ-cell tumors. Lancet 1994, 343:1130-1132

3. Moran CA, Suster S, Przygodzki RM, Koss MN: Primary germ cell tumors of the medistinum. Mediastinal seminomas-a clinicopathologic and immunohistochemical study of 120 cases. Cancer 1997, 80:691-698

4. Moran CA, Suster S: Germ cell tumors of the mediastium. Adv Anat Pathol 1998, 5:1-15

5. Schantz A, Sewall W, Castelman B: Mediastinal germinoma, a study of 21 cases with an excellent prognosis. Cancer 1972, 30:1189-1194

6. Bjornsson J, Scheithauer BW, Okazaki H, Leech RW: Intracranial germ cell tumors: pathobiological and immunohistochemical aspects of 70 cases. J Neuropathol Exp Neurol 1985, 44:32-46

7. Hoffman HJ, Otsubo H, Hendrick EB, Humphreys RP, Drake JM, Becker LE, Greenberg M, Jenkin D: Intracranial germ cell tumors in children. J Neurosurg 1991, 74:545-551

8. Wei YQ, Hang ZB, Liu KF: In situ observation of inflammatory cell-tumor cell interaction in human seminomas (germinomas): light, electron microscopic, and immunohistochemical study. Hum Pathol 1992, 23:421-428

9. Rozenblum MK, Matsutani M, Van Meir EG: Germ cell tumors. In Kleihues P, Cavenee WK. (eds). World Health Organization Classification of Tumors. Pathology and Genetics: Tumors of the Nervous System. Lyon, IARC Press, 2000, 207-214

10. Shinoda J, Yamada H, Sakai N, Ando T, Hirata T, Miwa Y: Placental alkaline phosphatase as a tumor marker for primary intracranial germinoma. J Neurosurg 1988, 68: 710-720

11. McIntyre A, Summersgill B, Grygalewicz B, Gillis AJ, Stoop J, van Gurp RJ, Dennis N, Fisher C, Huddart R, Cooper C, Clark J, Oosterhuis JW, Looijenga LH, Shipley J: Amplification and over expression of the KIT gene is associated with progression in the seminoma subtype of testicular germ cell tumors of adolescent adults. Cancer Res 2005, 65: 8085-8089 